\title{
The Role of Context in Interpreting and Translating the Qur'an
}

\author{
M.A.S. Abdel Haleem \\ SOAS, UNIVERSITY OF LONDON
}

This article argues that context plays a crucial role throughout the Qur'an in understanding, interpreting, and translating it into another language. It argues that insufficient regard has been paid to context in most translations of the Qur'an into English, as well as in commentaries on the Qur'an in both English and Arabic, in addition to other languages, all to the detriment of proper understanding. Let us first define what is meant by context. In our discussion in this paper, the term 'context' is used to refer to two things:

i) Parts of a statement that precede or follow a given word or phrase and influence its meaning, referred to in Arabic as siyāq ('context') or siyāq al-nașs ('textual context').

ii) The context of the situation: the set of circumstances or facts that surround any statement in the Qur'an. This is known in Arabic balägha ('rhetorical studies') as maqām, and in recent discussions is also referred to as siyāq al-mawqif.

Both categories will be seen to affect meaning. The second, maqām/siyāq al-mawqif, has historically been singled out for discussion in balāgha studies, and requires some elaboration.

Balāgha has historically been one of the most important disciplines for Qur'anic exegesis, and it began and developed around the central question of the appreciation of the style of the Qur'an, and especially its $i$ ' $j \bar{a} z$ ('inimitability'), as witnessed by such works as the Dalā'il al-i 'jäz ('Proofs of the Inimitability [of the Qur'an]') of 'Abd al-Qāhir al-Jurjānī (d. 471/1078).The importance of balāgha, especially 'ilm alma 'ānī ('study of meaning') and 'ilm al-bayān ('the study of eloquence'), for tafsìr in general is universally recognised in Arabic, and the attention paid to it by such commentators as al-Zamakhsharī (d. 538/1143) and al-Rāzī (d. 606/1209) gives their work particular distinction. One of the most important contributions of classical scholars of balāgha was their recognition of the concept of maqām and its role in determining the meaning of the utterance and providing the criterion for judging it. 'Ilm al-ma ' $\bar{a} n \bar{l}$, the first of the three branches that constitute the discipline of balāgha, was defined as being the one that discusses mutāabaqat al-kalām li-muqtada al-hāal 
('the conformity of the utterance to the requirements of the situation'). Al-Khatị b alQazwīnī (d. 739/1338) explains: ${ }^{1}$

The context (maqām) that demands the definite, generalisation, prepositioning of part of a discourse, and inclusion [of specific words] differs from the context that demands the indefinite, specification, postpositioning and omission; the context for disjoining differs from that of joining; the situation that requires conciseness differs from that requiring expansiveness. Discourse with an intelligent person differs from discourse with an obtuse one. Each word with its companion is suited to a specific context. A high standard of beauty and acceptability of speech depends on its appropriateness to the situation and vice versa.

Tammām Hassān (1918-2011) pointed out that when scholars of balāgha said 'li-kull maqām maqūl' ('every situation has its own suitable expression') and 'li-kull kalima ma 'a șạhibatihā maqām' ('every word combined with another has its own suitable context') they hit on two remarkable rhetorical principles that could equally apply to the study of other languages. ${ }^{2}$ In doing so, they were a thousand years ahead of their time, since recognition of maqām ('the context of the situation') and maqāl ('the statement that suits the context') as two separate bases for the analysis of meaning was arrived at only recently in modern western linguistic thinking. When Malinowski coined his famous term 'the context of the situation' in 1923 he was unaware that Arabic rhetoricians had used a similar term a thousand years earlier.

This great discovery on the part of scholars of balāgha came about as a result of their investigation into Qur'anic style and inimitability ( $i j \bar{c} z$ ). Even literary critics such as Ibn al-Athīr (d. 630/1239) ${ }^{3}$ relied heavily on Qur'an citations to demonstrate stylistic excellence in the use of language. The very language and style of the Qur'an make consideration of context essential, as it uses a highly concise mode of expression that does not explain everything. For example, omission is a very apparant feature of the Qur'an, and often occurs because the Qur'an was speaking to a community that was already familiar with the events or ideas it refers to, apparently in passing, and without giving lengthy explanation. This means that sometimes a phrase, sentence, or verse is so condensed that it does not allow easy identification of context.

A further crucial feature which relies on identification of context is al-ishtirāk ('polysemy') in individual words, and to a lesser extent in structure. Qur'anic polysemy is recognised in the well-known term wujüh al-Qur'ān ('the multiple meanings of words in the Qur'an'), the name applied to an analytical approach which originated early in the first century AH and became well developed, resulting in scores of texts that were produced over five or six centuries. ${ }^{4}$ To give but one example, the word kitāb was found to occur with ten different meanings in the Qur'an. Given this feature of polysemy, the only guiding factor in determining the meaning is context. 
As we shall see, some exegetes were in the habit of listing all the possible alternative meanings of a word from a dictionary in their discussion of its meaning in a given verse, saying, 'It means either this or that, or that or ...' rather than selecting the meaning that suited the context and discarding the rest, as will be seen below.

I will now discuss some examples of wujūh and their translations, starting with the word al-hakim. This is a remarkable example of the phenomenon of wujūh, occurring as it does 97 times in the Qur'an. Morphologically it is an intensive form of the adjective (sifa mushabbaha), and this itself does not seem to present a problem, but its lexical meaning does. The verbal root is $h-k-m$ but the word al-hakim can be assumed to be derived from hikma, meaning 'wisdom', or from hukm, which means 'decision' / 'judgement'. All the English translators of the Qur'an that I have consulted have consistently opted for the first meaning in all 97 examples, leading them to render this term along the lines of 'wise'. This may have been based on the first meaning that occurs in dictionary entries, ${ }^{5}$ or translators may have been influenced by al-Bayḍāwī's Tafsīr, which has historically been the most readily available for Euro-American scholars of the Qur'an since it was edited and published in Europe at a relatively early date. ${ }^{6}$ Al-Bayḍāwī takes the first occurrence of al-hakìm, in Q. 2:32, to refer to God's wisdom (hikma). However, al-Bayḍāwī, as will be shown later, is known to be atomistic in much of his approach, and focuses on the word in hand in isolation from its surrounding context. Translators, starting with Sale, seem to have copied the meaning of 'wise' from their predecessors without actually questioning whether this translation of al-hakim fits the context or not. One example will be discussed here, Q. 2:208-209: Do not follow in the footsteps of Satan, for he is your sworn enemy. If you backslide after clear proof has come to you then be aware that God is 'aziz and hakim, in which all the various translators render hakim as 'wise'.

The context in which hakim occurs here is a threat that God has the power to decide to punish the believers if they backslide. An Arab Bedouin, who was not a reader of the Qur'an, had the quick wits, when he heard a reciter misreading this verse by using the words ghafūr ('forgiving') and rahìm ('merciful') instead of 'azīz ('almighty') and hakim, to say 'If this was the speech of God, He would not say so. Al-Hakim would not mention forgiveness in the context of backsliding because this will encourage [people] to sin more'. When the reciter corrected it to 'azizzun hakimun, the Bedouin said, 'Yes, that is how it should be 'azza fa-hakama, meaning 'He possessed the might, and so He passed judgement'. ${ }^{7}$ Thus, clearly from the context, al-hakim must be translated on this occasion to convey the connotative sense of 'He who judges' rather than 'He who is wise'. Given that al-Hakim is an attribute of God, it is clear that care should be taken to identify its correct meaning in Arabic before translating.

The word al-Rahmān denotes another divine attribute which has also been mistranslated because translators have not paid due regard to the context in which it occurs. Many translators have rendered this epithet as 'the Merciful' or 'the All- 
Merciful', but this clearly does not fit in many situations. For instance, Q. 21:42 is variously rendered as the following:

Who shall keep you safe from the All-Merciful by night or day? (Khalidi)

Who will guard you night and day from the Merciful? (Jones)

Who shall guard you by night and in the daytime from the All-merciful? (Arberry)

These translations are problematic: Khalidi's concept of 'Keeping someone safe from the All-Merciful', in particular, sounds somewhat contradictory. In my own translation of this verse I have instead opted for 'Who could protect you night and day from the Lord of Mercy?' on the basis that it is the lordly and powerful aspect of God that is operative in this context. This translation retains the idea of God's mercy, but also conveys the sense of lordship that has power and authority.

Another example of contextually inappropriate translation can be found in Jones' translation of Q. 19:45, in which Abraham says, 'My father, I fear that some punishment from the Merciful will touch you.' The idea of punishment coming from the Merciful does not quite fit in this context either, which again demands something more like 'the Lord of Mercy'. This reading of the connotative range of the epithet alraḥmān is also supported by Tammām Hassan in an article in which he studied the various occurrences of al-raḥmān in the Qur'an and concluded that it involves power and sovereignty. ${ }^{8}$

Walad is another example of a word that can have significant implications for how a specific verse is read, depending on how it is translated. In his translation of Q. 19:88, Arberry renders walad as 'son', giving:

They say, 'The All-Merciful

has taken unto Himself a son.

You have indeed advanced something hideous!

The heavens are wellnigh rent of it

and the earth split asunder

and the mountains wellnigh fall down crashing

for that they have attributed

to the All-merciful a son: and it

behoves not the All-merciful to take a son.

He is not alone in this: Alan Jones and Tarif Khalidi, among others, also render walad as 'son', but this is in fact a modern Arabic usage. In classical Arabic walad denotes 'offspring', whether singular, plural, male, or female. ${ }^{9}$ It could be argued that such translators were influenced by thinking about the early part of the sura which mentions 
Jesus, especially verse 35, It is not for God to take a son unto Him. However, Jesus' story comes only in in the early part of the sura. Later on (vv. $77 \mathrm{ff}$.) the sura switches subject matter to refer to the idolaters (mushrikün) of Mecca. In verse 81-82 we are told that They have taken other gods beside God to give them strength, but these gods will reject their worship and will even turn against them. Verse 88, cited above, refers to this same group of people, and is thus referring to the 'other gods' that the polytheists have chosen to worship, rather than Jesus. The wider context (siyāq alnașs) makes this very clear. Only when the verse is taken in isolation could al-walad be claimed to mean 'a son'. When a word used in the Qur'an has more than one meaning (wajh), as is the case here, the proper way of reading it is to bear the siya $q$ in mind when determining the correct meaning of the word. Furthermore, in arriving at their choice of translation, translators should also pay regard to the meaning of Arabic words at the time of the revelation of the Qur'an.

\section{Wujūh Connected with the Prophet Muḥammad}

We shall now give some examples of wujūh connected with the Prophet Muhammad. The first is the short verse Q. 74:6, wa-lä tamnun tastakthir, which has been variously rendered as:

\section{Give not, thinking to gain greater (Arberry)}

Do not show favours seeking gain (Jones)

\section{Give not, hoping to gain more (Khalidi)}

The verb tamnun is here understood by all three translators to mean 'give' or 'show favour'. This is, admittedly, the first meaning that comes to mind but it cannot be suitable for the maqām or the siyāq al-nașs in this instance. Sura 74 is a very early sura addressed to the Prophet, which begins with a call to prophethood: $O$ thou shrouded in thy mantle, arise and warn! Thy Lord magnify, thy robes purify and defilement flee! Give not ... (Arberry). The historical fact is that, at this particular moment in time, the Prophet had no material goods to give away in order to gain anything. Rather, when viewed in the light of historical context, this verse can be read as meaning Do not weaken, feeling overwhelmed. The context is further elaborated in the preceding sura (Q. 73), which deals with the same situation, i.e. the time that Muhammad was called to prophethood, when he is asked to keep vigil at night ... We shall cast upon thee a weighty word (Arberry), We shall send a momentous message down to you (Haleem). The Qur'anic treatment of this makes it clear that the Prophet felt awed by these commands, and had to be told wa lā tamnun tastakthir, Do not weaken, feeling overwhelmed by the many requests made of him. This is contextually confirmed by the following verse (verse 7), which states wa-li-rabbika fa'şbir (Be patient unto thy Lord, Arberry). The rationale behind this alternative reading is that the verb tamnun has another wajh, which can be seen in the phrase hablun manin, 
which means 'a weak rope'. ${ }^{10}$ When used in conjunction with the word manna ('task'), the verb can mean 'to be tired or weakened by a task'. Thus, in Q. 74:6 the siyāq determines that tamnun be read with the meaning of 'weaken', in the light of the intratextual evidence in the previous sura relating to the Prophet and how he felt in his early calling.

Also connected to the Prophet are two examples of wujūh involving the definite article al- which can be jinsiyya ('generic', referring to everything covered by the following noun) or 'ahdiyya ('specific', referring to a specific entity already mentioned or known to the addressee). The first can be seen in the example of the word al-nās in Q. 17:94, here translated by Pickthall:

And naught prevented mankind (al-nās) from believing when the guidance came unto them save that they said: Hath Allah sent a mortal as [His] messenger?

Arberry gives 'men' instead of 'mankind' in his translation of this verse, while Khalidi gives 'mankind', and so does Jones. However, in my translation I have chosen to give 'these people' for al-nās. The fact is that 'mankind' could not be intended here, since we know that many peoples had received human messengers and humanity as a whole could not be said to find the idea of prophets strange or a reason for not believing. When viewed in the context of the previous verse, a different picture emerges. In this verse the disbelievers of Mecca challenge the Prophet, saying they will not believe until he brings down God or the angels for them to see face to face. We are also told in other verses of the Qur'an, for example Q. 15:7 and Q. 25:7, that the Meccans demanded that an angel should come down to support the Prophet: they wanted an angelic messenger rather than a human being. Thus, the immediate and wider context of the Qur'an make it clear that the $n \bar{a} s$ who presented such challenges to the Prophet in this verse were not humanity in general, but 'these people [of Mecca]'. Such lack of awareness of al-al-'ahdiyya has given rise to numerous other examples of misinterpretation.

\section{Oaths in Context}

An obvious illustration of the crucial role of context can be seen in a number of suras which begin with an oath on the pattern wa'l-fä ilät (Q. 37, Q. 51, Q. 77, Q. 79, and Q. 100). These oaths present an important issue, in view of the problems they cause in Qur'an translation, and so deserve some elaboration. The oaths in these suras consist of an implied noun described by an active participle. This is a common structure in Arabic, according to which the meaning of the adjective is obvious in the culture without any need for the described noun. Thus, Sūrat al- 'Ádiyāt (Q. 100) begins with the oath wa' $l$ - 'ádiyāt. The root of al- 'ädiyāt is ' $-d-w$ ('to run, speed, gallop, dash, race, charge'), so that a literal reading might be By the chargers. Even without the noun being supplied, this oath can thus readily be understood to refer to horses. 
When dealing with these oath clusters in the Qur'an, al-Bayḍāwī and other classical exegetes had a tendency to look at the individual words in isolation. This meant that although they did understand the contextual reading of these phrases, they were keen to supply all possible alternatives of the individual word, without relying on context to eliminate unsuitable alternatives. In al-Dhäriyāt (Q. 51), verses 1-6, four items are sworn by:

wa'l-dhāriyāti dharwan

fa'l-ḥāmilāti wiqran

fa'l-jāriyāti yusran

fa'l-muqassimāti amran

innamā tū 'adūna la-ṣādiq

wa-inna'l-dīna la-wāqi

In his commentary on the first verse, wa 'l-dhāriyūti dharwan, al-Bayḍāwī accordingly gives three alternative interpretations of this phrase: that it can refer to (i) winds, because they scatter dust, (ii) women because they produce and spread children, and (iii) causes, because they produce creatures, angels and others.

For the second verse, fa'l-hāmilāti wiqran, al-Bayḍāwī gives four possible explanations, that the 'heavily laden' describes (i) clouds, because they carry rain, (ii) winds, because they carry clouds, (iii) women, because they carry children, (iv) causes, because they produce creatures, angels, and others.

In his reading of the third verse, fa'l-jāriyāti yusran, he lists (i) ships, because they run in the sea, (ii) winds, because they run, and (iii) stars, because they run on their courses, while for the fourth and final item, fa'l-muqassimāti amran, he suggests (i) angels, because they share out the rain and other provisions, (ii) causes that distribute anything, and (iii) winds, because they distribute rain. ${ }^{11}$

Clearly this type of reasoning makes it possible to go on indefinitely suggesting words that happen to have a possible meaning that relates to individual words in the oath, but in isolation from the context. As is clear from the following verses, 5 and 6, the context here is that of an oath to prove the truth of the Resurrection. However, in his discussion of the various potential meanings of the oaths al-Bayḍāwī does not relate the items sworn by (al-muqsam bihi) to the object of the oath (al-muqsam 'alayhi). He gets distracted by the items sworn by from seeing the objectives of the whole series, which is an oath swearing by the wind that scatters rain, carries clouds, and speeds easily to reach their destinations and distribute the rain there. That it refers to the winds is very obvious from other Qur'anic verses where this trope is stated explicitly, such as Q. 7:57, ${ }^{12}$ Q. 30:48, ${ }^{13}$ and Q. 35:9 ${ }^{14}$. Al-Bayḍāwī himself was aware of this reading of the oath cluster, and listed it for all the verses but among other possibilities, and so he did not see the connection and what the whole passage is driving at. In a previous publication, I have proposed that these verses can only realistically be read as an 
argumentation oath, ${ }^{15}$ intended to prove the Resurrection, and have given the following translation:

By those [winds] that scatter far and wide, that are heavily laden, that speed freely, that distribute [rain] as ordained, what you are promised is true: the Judgement will come.

The oath is meant to prove that just as winds drive clouds and rain to a dead land, which will sprout with life, in this way you will be brought out [from the earth] (kadhälika tukhrajūn Q. 7:57) on the Day of Resurrection. Furthermore, He who sent the rains is the One who will bring the dead back to life (Q. 30:50). Ignoring the maqām, the siyāq and intratextuality in all the oaths in the five suras listed above makes the passages unclear and create a non-sequitur with the object of the oath, as compared with other parts of the Qur'an that clearly and specifically mention the simile of bringing plants out of the dead land and bringing people out of their graves.

\section{Consistency and wujūh}

Paying regard to wuju $h$ in translation may lead some to think there is a glaring example of inconsistency when the same word is translated in different ways. There is not. Once you have determined the meaning or wajh of a word, you have to be consistent in using the same translation for the word whenever it occurs in that meaning (wajh). However, automatically forcing one meaning on a word that has multiple wujūh can, as I hope is clear from the discussion above, lead to inaccuracy or absurdity. Take for example the word al- 'älaminn. Al-'älamīn occurs 73 times in the Qur'an, in widely different contexts, which means that a consistent translation using only one word would create havoc. It can mean 'all worlds' as in Q. 1:2, or 'all women' in Q. 3:42, or 'all other people' in Q. 26:165. This last verse expresses Lot's objection to the practice of the people of his town. In his translation, Jones gives 'Do you come to the males of created beings?' What is intended is human males and Lot is objecting to this. To translate al- 'älamīn as all created beings makes it far wider than human males. In a similar manner, Arberry gives, 'male beings'.

Another example of multiplicity of meaning can be seen in the word al-kitāb, which occurs 1,230 times with ten different meanings in the Qur'an, variously meaning scripture, writing, the records of deeds, or a legal document manumitting a slave, for example, or recording a debt. To use the word 'book' consistently would not work, nor do I translate the word kitāa when referring to the Qur'an as 'book' because it clearly refers to the revelation of a single passage or sura, each revealed separately over 23 years, and not to a book in the modern sense. The cherished rule of consistency should not be applied mechanically and the Qur'an should be treated as a text on its own terms. 
Wujūh do not obtain only with individual words, but can also be seen to obtain in a more complex lexical structure where only the context can determine which option is correct, for example a situation in which a statement can either be seen to be complete at one point or needs to continue in a following statement. Thus, Q. 5:97 begins: God has made the Ka'ba-the Sacred House-a means of support for people, and the sacred months, the sacrificial animals, including the garlanded. This statement is potentially complete, but it is followed by the phrase dhālika li-ta 'lamū anna'llāha ya 'lamu mā fíl'l-samāwāti wa'l-ard, which has variously been translated as:

so that you may know that God knows all that is in the heavens and all that is in the earth (Jones)

this is in order that you may know that God knows what is in the heavens and what is on the earth, and that God is Omniscient (Khalidi)

so that you may know that God has knowledge of all that the heavens and the earth contain (Dawood)

Exegetes have also understood this as a clause of purpose with lām al-ta 'līl ('lām of purpose' $)^{16}$ such that it reads 'in order that you should know that He knows ...'. Sensing perhaps that it is questionable that God should have established the Ka 'ba and the sacrificial animals for the purpose 'that we know that He knows' and so on, exegetes try to explain this reading in various ways, including that His knowledge is important to determine that people need the Ka'ba and the sacred months and so on. They take the context to be showing that God has extensive knowledge. I would argue that this is not the correct way of reading the text.

My suggestion is that the phrase should stop at the mention of the garlanded animals, before dhālika. Then dhālika itself is a complete sentence meaning, 'He ordained all this', then a full stop followed by an order (läm al-amr) for the readers to bear in mind that God has knowledge of all things including whether they will obey or not, and that He has power over everything and can punish those who infringe His orders. This reading of verse 97 is supported by two things. Verse 2 of the same sura comprises an enumeration of the things God has ordained and an order that they should not be violated, ending with the phrase beware of God because He is shadīd al- 'iqāb ('severe in punishment'). This same exact phrase i 'lamū anna'llāha shadīdu'l- 'iqāa, occurs again in verse 98, that is immediately following the verse under discussion. Dhälika, which I suggest above be viewed as a full sentence in verse 97, occurs similarly as a full sentence in other parts of the Qur'an, for instance, Q. 22:30 and 60. The context in verse 5:97 is of warning and threatening, not of informing about God's extensive knowledge. It is this context that determines the segmentation of the material and the correct wajh, reading and translation, of the passage. 
In another example, Q. 6:38, the disbelievers have rejected the Prophet and his teachings. God directs him (Q. 6:36) that he should not worry about these people since they are like the dead who cannot hear. Then, in verses 37-38, we read in Arberry's translation:

They also say, 'Why has no sign been sent down to him from his Lord?' Say ...

No creature is there crawling on the earth,

No bird flying with its wings,

but they are nations like unto yourselves.

We have neglected nothing in the Book (al-kitāb);

then to their Lord they shall be mustered.

Here the obdurate disbelievers have demanded a sign, and they are shown one in the communities of birds and animals. Arberry's rendition of this verse continues: We have neglected nothing ... to their Lord they will return, following the conventional understanding that this phrase refers to the fact that even birds and animals are mentioned in the Qur'an, and that they will be gathered on the Day of Judgement before God. However, in my opinion, this is misleading: according to a reading which is sensitive to context there is a shift in focus that begins with the phrase We have neglected nothing, which refers not to birds and animals but to the disbelievers mentioned earlier (in v. 36), to warn them that God has recorded everything in their records of deeds and that they will be gathered before him for Judgement. This is supported by the fact that the following verse (39), Those who deny Our signs are deaf and dumb, in darkness, reiterates verse 36, Only those who can hear will respond, the dead will be raised by God and then will return to Him. The context of the phrase, then, is warning the obdurate deniers of God's revelation rather than providing information about the resurrection of animals and birds. Those who ignore context incorrectly segment the material and take al-kitāb to refer to the Qur'an rather than God's record of deeds. Such a reading of this verse has theological implications as there are those who, taking this instance of al-kitāb as referring to the Qur'an, use it to justify a claim that we need only rely on the Qur'an and not turn to other books, on the basis that God has said We have neglected nothing in the Book.

\section{The Sword Verse}

When the [four] forbidden months are over, wherever you encounter the idolaters, kill them, seize them, besiege them, wait for them at every lookout post; but if they repent, maintain the prayer, and pay the prescribed alms, let them go on their way, for God is most forgiving and merciful (Abdel Haleem)

The 'Sword Verse' is perhaps one of the most famous Qur'anic verses and one of the most often misunderstood and (mis)quoted by propagandists, extremists, and by some 
modern orientalist academics. For example, Michael Cook gives the following translation of Q. 9:5:

Then, when the sacred months are drawn away, slay the polytheists wherever you find them, and take them, and confine them, and lie in wait for them at every place of ambush. But if they repent, and perform the prayer, and pay the alms, then let them go their way: God is Allforgiving, All-compassionate.

He then interprets the verse as follows: ${ }^{17}$

In other words, you should kill the polytheists unless they convert. A polytheist (mushrik) is anyone who makes anyone or anything a 'partner' (sharīk) with God; the term extends to Jews and Christians, indeed to unbelievers.

This is an extraordinary assertion when applied to the Qur'an, which has very definite separate terms for Jews, Christians, and unbelievers. Moreover, as will be shown conclusively in the discussion below, the verse refers to just one group of polytheists, rather than being a general indictment, and the instruction to slay them absolutely does not 'extend to Jews and Christians, indeed to unbelievers'.

Cook uses Q. 9:5 in his discussion to contrast this interpretation of the Qur'anic verse with 'a modern Western society, where it is more or less axiomatic that other people's religious beliefs ... are to be tolerated and perhaps even respected'. ${ }^{18}$ This particular criticism of Islam has become widespread. For example, in 2006, Pope Benedict XVI in his Regensburg Lecture, said 'surah 2, 256 reads: "There is no compulsion in religion." According to some of the experts, this is probably one of the suras of the early period, when Mohammed was still powerless and under threat. But naturally the emperor also knew the instructions, developed later and recorded in the Qur'an, concerning holy war.' ${ }^{19}$ Indeed, this verse has been similarly interpreted by many Muslims, both in the past and in modern times, and has been used by extremists and terrorist groups who wish to justify their views and actions. In the rest of this article, I will undertake a close analysis of the text alongside an examination of the opinions expressed by two authors: the modern academic Michael Cook quoted above, and the fifth/eleventh-century writer Ibn Salāma. Through these two authors, I will discuss the mythology that has been created and maintained about this verse. As should become clear in the following discussion, Q. 9:5 cannot be correctly understood when isolated and ripped out of its context. Such a strategy is misleading and contrary to sound linguistic norms and proper academic practices. In fact, the verse should be read together with the whole of the first section of the sura (verses 1-28), which are all interconnected and deal with one and the same theme. This section will thus provide a contextualised analysis of Q. 9:5 in the light of these verses, as they are presented in 
the Qur'anic text. Arberry's translation, also used by Cook, will be cited for this purpose.

Q. 9:5 begins with the phrase Then, when the sacred months are drawn away, slay the idolaters. Earlier in the sura, in their announcement of the impending termination of the treaty you [believers] made with the idolaters, verses 1 and 2 define the target audience 'idolaters', referred to in Q. 9:5, as the idolaters with whom you [the Muslims] made a covenant. Verse 1 further announces to these idolaters, Journey freely about the land for four months, meaning that, even after the idolaters had broken the treaty, the Muslims were not permitted to enter into a state of war with them at once. Four months grace was declared, during which the idolaters could go about their ways as before, without any interference, although they were reminded that God degrades the unbelievers. We are told that this announcement was made in a way that ensured it reached all parts of Arabia, at the peak of the pilgrimage: [there will be] a proclamation from God and His Messenger to all people, on the Day of the Greater Pilgrimage: 'God is quit, and His Messenger, of the idolaters' (Q. 9:3). As always with the Qur'an, it then leaves an opening for the idolaters and advises, So if you repent, that will be better for you ... In the following verse, it then excepts those of the idolaters who honoured the treaty you made with them, and who have not supported others against you: fulfil your agreement with them to the end of the term. God loves those who are mindful of Him.

As a result, when read in the context of the preceding four verses of this sura, verse 5 clearly and very explicitly deals only with those idolaters who did not honour their treaty and who supported others against the Muslims. In other words, those who, by breaking the peace treaty and supporting others against the Muslims, had themselves entered into a state of war. The definite article al- in fa'qtulū'l-mushrikin ('kill the idolaters') is not a generic al-(al-jinsiyya), but a specific al- (al-'ahdiyya), referring only to those mushriks mentioned in verses 1-4. 'Al-' al- 'ahdiyya is a basic feature of Arabic grammar. In his comments cited above, Cook appears to have misinterpreted this al- because, as he admits, he relies on Arberry, not on the Arabic text. ${ }^{20}$ Moreover, Cook isolated verse 5 from everything around it. If read in the original Arabic, or even in translation, with its surrounding verses (verses 4, 5, and 6 onwards) the correct interpretation becomes clear. In Cook's discussion, the Arabic text and context are both neglected.

Similarly, Arberry's translation of the imperative kill the idolaters is also misleading, and should actually read you may kill the idolaters. In Arabic linguistics and in Islamic jurisprudence, the imperative form covers a vast range of meaning (Muhammad Șālih has recently surveyed 15 different meanings.) For example, it can be used to issue orders, indicate permissibility, or in the context of advice and encouragement. ${ }^{21}$ The usage of the imperative in this instance conforms to the juristic rule (deduced from analysis of the text of the Qur' an and agreed upon by the majority of jurists) of al-amr 
ba'd al-hazr li'l-ibāha (that an imperative form that comes after prohibition indicates permissibility). ${ }^{22}$ To give one example of the 'imperative of permissibility': in Ramaḍān Muslims refrain from eating and drinking during the daytime. When the Qur'an tells them, When night time falls, eat and drink, it is not ordering them to eat and drink, it merely reinstates the original state of permissibility. ${ }^{23}$ In accordance with this, the expiry of the four months' notice, during which Muslims were not permitted to fight the polytheists who broke the treaty, did not actually order them to fight, but rather returned them to the original state of permissibility. It simply meant that there was no further obligation to refrain from fighting the polytheists. Thus, al-Rāzī categorically states, 'When the four months are ended, God Almighty permitted (adhina fi) four things .... ${ }^{24}$

As mentioned above, in his comment on this part of Q. 9:5, Cook makes the exegetical statement 'in other words "kill them unless they convert".' However, when the verse is examined in context, it becomes clear that this reading cannot be correct, since killing is only one of four permitted alternatives mentioned, the others being (citing Arberry's translation), to take them (i.e. arrest or capture them), confine them, and lie in wait for them at every place of ambush.

The second part of Q. 9:5 reads, But if they repent, and perform the prayer and pay the alms, then let them go on their way. This should not be read as a condition for not killing: it does not mean that Muslims should go on killing polytheists until they repent. When one looks at the Arabic terms used here, one notices the use of the particle in, meaning 'if'. This is in contrast to the alternative particle hattā which has two meanings: $t a$ ' $l \bar{l} l$, indicative of purpose ('so that') and ghāya, indicating a limit ('to the point of', 'until'), used, for example, in Q. 2:193, Fight them until (hattā) there is no more persecution. ${ }^{25}$ The instruction in Q. 9:5, If they repent [...] let them go on their way, for God is most forgiving and merciful, thus means that 'you too should forgive them and not continue to pursue them'. This interpretation is confirmed by Q. 9:11, which says: If they repent, keep up the prayer and pay the prescribed alms, then they are your brothers in faith. This statement also opened the door for any polytheist who wished to take this option. The interruption of the sentence in the way observed here is noteworthy. It has already been demonstrated that in verse 4 the exception is placed before verse 5 rather than inside it. This is an example of the way the Qur'an is so restrictive and careful whenever it deals with the theme of fighting. ${ }^{26}$ This level of caution can also be observed in the passage under discussion in the repetition of the conditional 'if' in verses 3,5, 6, 11, and 15. There is also repetition of illa ('except for') in verses 4 and 7. Restriction can also be seen at the ends of the verses, where Muslims are urged: God loves those who are mindful of Him (verse 4); let them go their way, God is most forgiving and merciful (verse 5); remain true to them, God loves those who are mindful of Him (verse 7); God will accept the repentance of 
whomever He wishes, God is all knowing and wise (verse 15); and God knows well all that you do (verse 16).

\section{Is There Anything New in the 'Sword Verse'?}

Sura 9 is, chronologically speaking, the last sura to mention fighting. The permission it gives to fight and arrest those polytheists who had broken their treaty and were thus in a state of war with the Muslims did not bring anything new. Q. 22:39, chronologically the first verse related to the permissibility of fighting, states: Permission is given to those who have been attacked, because they have been wronged, and God is able to support them. Q 8:56-58, which are traditionally dated to $2 \mathrm{AH}$, after the Battle of Badr, some seven years earlier than the 'Sword Verse' comprise the following revelation:

[Those] who, whenever you [Prophet] make a treaty with them, break it, for they have no fear of God. If you meet them in battle, make an example of them to those who come after them, so that they may take heed, and if you learn of treachery on the part of any people, throw their treaty back at them, for God does not love the treacherous (Abdel Haleem).

The phrase throw their treaty back at them in Q. 8:57 is mirrored in Q. 9:7-8, How could there be a treaty between such polytheists and God and His Messenger? Further to this, Sura 2, another sura to be revealed prior to the Sword Verse, includes the instruction to Fight, in God's cause, against those who fight you, but do not overstep the limits. God does not love those who overstep the limits (Q. 2:190-4). Here, the Muslims are clearly forbidden to overstep limits; Q. 9:10 describes the polytheists as the ones who overstep the limits. Again, in Sura 2 we read Kill them [those who fight you] wherever you encounter them, ${ }^{27}$ and drive them out from where they drove you out (Q. 2:191). This is no different from the instruction in Q. 9:5 to Kill them (i.e. the polytheists who have broken the treaty) wherever you encounter them. Similarly, Sura 4, another Medinan sura, which predates Sura 9, referring to the hypocrites and warning the Muslims against allying themselves with them, states: If they turn on you, seize them and kill them wherever you encounter them (Q. 4:89).

\section{The Sword Verse and Abrogation}

Modern scholars are not the only ones guilty of misreading the Qur'an based on a noncontextual reading of the text. The premodern exegete, grammarian, and teacher of Qur'anic recitation Hibat Allāh Ibn Salāma (d. 410/1020), ${ }^{28}$ the author of al-Nāsikh wa'l-mansūkh ('The Abrogating and the Abrogated'), is an extreme example of someone who adheres to the concept of naskh (abrogation), meaning, in his view, that some verses cancel others, rather than nuancing and contextualising each other. According to him, the 'Sword Verse' abrogated 124 verses in the Qur'an, ${ }^{29}$ and, 
amazingly, he considers the first main clause of the verse, kill the polytheists wherever you find them, to be abrogated by final instruction that if they repent and perform the prayer, and pay the prescribed alms, let them go their way. ${ }^{30}$ Furthermore, he then goes on to state that God made a further abrogation of the repentance phrase in verse 6 , and if any of the polytheists should seek your protection [Prophet], grant it to him so that he may hear the word of God.

Ibn Salāma's approach here shows something of how he understands the word 'abrogation', and how this understanding leads him to make sweeping claims about abrogation in the Qur'an which, unfortunately, are still being repeated. This gives us an example of how, in the Islamic tradition, as in any academic tradition, authors often uncritically perpetuate the claims or statements made by their predecessors. Although this practice may be considered to illustrate academic integrity in that it actively works against the suppression of information, on close examination much of what Ibn Salāma said will not stand up to proper linguistic or textual analysis. In fact, Ibn Salāma shows total disregard for context and wrenches short statements out of place, as can be seen from the few examples addressed below:

With regard to Q. 2:83, We took a pledge from the Children of Israel: Worship none but God, be good to your parents and kinsfolk, to orphans and the poor; speak nicely to people ..., ${ }^{31}$ Ibn Salāma considers the order in this verse to speak nicely to people to be abrogated by the Sword Verse. ${ }^{32}$ Yet, on a purely logical basis, how can a description of an instruction given at the time of Moses to the Children of Israel on the subject of general behaviour and deportment to others be abrogated by a specific permission given to the Muslims at the time of Muhammad to fight a particular group of polytheists who had broken their treaty? This instance alone clearly shows Ibn Salāma's total disregard for context as a methodological principle.

In the case of Q. 40:11-12, verse 11 describes how the polytheists in Hell admit Lord [...] now we recognise our sins. Is there any way out?, in response to which, in verse 12, they are told by the angels, This is all because, when God alone was invoked, you rejected this, yet when others were associated with Him you believed. Judgement belongs to God, the Most High, the Most Great. Ibn Salāma blatantly and mysteriously asserts, against the context, that 'The meaning of the ruling on this verse in this world is abrogated by the Sword Verse. ${ }^{33}$ What he considers abrogated in Q. 40:12 are the words Judgement belongs to God, the most great. It is amazing that this reported statement, made by the angels to those in Hell in the Hereafter, could be interpreted as being abrogated by a verse giving permission to fight the polytheists who broke the Hudaybiyya treaty.

In the final example, Q. 76:6, God speaks of the righteous on the Day of Judgement drinking from a spring for God's servants, which flows abundantly at their wish. In verse 7 the Qur'an gives, as a reason for this grace, the fact that they fulfil their vows, 
they fear a day of widespread woes; they give food to the poor, the orphan and the captive, though they love it themselves, saying, 'We feed you for the sake of God alone ...'. In a similar manner to the examples above, paying no attention to the context of the verses at all, Ibn Salāma tells us that giving food to the captive was abrogated by the Sword Verse! ${ }^{34}$ At the end of his book, Ibn Salāma even goes so far as to assert that, "everything in the Qur'an of the type "turn away from them", "bear patiently with what they say", "ignore them", "be patient as befits you", "bear with them graciously" and all similar verses are abrogated by the Sword Verse'. ${ }^{35}$

\section{Conclusion}

In the previous discussion we have seen the crucial importance of context in determining meaning and achieving accurate and effective interpretation and translation. We have also seen that the feature of wujūh, multiple meanings, only one of which is demanded by the context, is very much an integral part of the style of the Qur'an and that the concept of context, which is considered one of the finest discoveries of Arab scholars of balāgha, came about as the result of their studies of the Qur'an. Therefore, in interpreting the Qur'an and translating it into another language, context is a vital consideration. The effects of siyāq are not confined to determining the meaning of words but also apply to considerations such as whether something is stated or omitted, the order of the material, and the amount of information given. For instance, in Sürat al-Isrä' (Q. 17), verse 101, we are told, We have given Moses nine clear signs ... To understand why this is mentioned here, we have to have read verses 90-93, in which the Meccans challenge the Prophet, asking for eight miracles, and saying, for instance, We will not believe in you until you cause a spring to gush out of the earth ... This naturally saddened the Prophet, and so he is reassured in verse 101 that Moses was given nine miracles and Pharaoh still rejected him after all these and so was punished. In the case of this particular verse, it is essential to know the textual context within the sura to understand why nine signs are mentioned here.

Similarly, in the Qur'an, the context of the sura can determine the order of material in that sura and the amount of material used. For instance, Sura $26 \mathrm{Al}$-Shu 'arā' begins by showing how grieved the Prophet was by the Meccan disbelievers rejection of him. To strengthen the Prophet's heart, seven earlier prophets are cited, with details given of how their communities responded and what punishment the disbelievers received. Significantly Moses is put first, as he too was afraid that his people would call him a liar, saying that he would be stressed and tongue-tied and asking God to send Aaron too to help him. The story of Moses then occupies 58 verses. In contrast, in Q. 54, Sürat al-Qamar, where five prophets are mentioned, the last of these relates to Moses, who is not even mentioned by name. Instead, very briefly in two verses, the story concentrates on Pharaoh's people rejecting all warnings and signs, 'so God seized them mightily'. Sura 54 focuses on warnings being sent to people, how they rejected 
them, and how mightily they were punished, all given briefly. Here, a long narration of Moses' story does not fit the context.

This principle of why something is mentioned at one particular point also applies to Sürat al-Baqara, verses 238-239: Take care to do your prayers, praying in the best way and stand before God in devotion. This comment is given in the middle of the discussion on divorce, which addresses a point at which the two divorcing parties are possibly engaged in acrimonious hostility. They are asked to stand and perform the prayer and then go back to the discussion, hopefully in a better mood. The same principle applies to Sürat al-Má'ida, verse 6 . In the middle of giving instructions to believers to keep away from unhealthy food and illicit sexual relations, the Qur'an again instructs people to go to the prayer, but before that to cleanse themselves, making cleanliness one of the best blessings of God. In a similar vein, the significance of the order in which material is presented can be seen, for example, in Q. 18:2, where we are told that the Qur'an is sent to the Prophet to give warning of severe punishment from God [for the idolaters] and to give glad news to the believers, whereas in Sürat al-Fușsilāt (Q. 41), it says bashīran wa-naẓiran in the reverse order because of the context.

Greater awareness of the importance of the context that frames specific verses counters and corrects any perceptions that suras are chaotic in construction, or that the Qur'an makes illogical statements or historical inaccuracies, that Qur'anic rhyme is merely for embellishment, and that the Meccan suras are an imitation of saj 'al-kuhhān (soothsayer's rhetoric). Likewise, context has theological implications for readings that claim that the teachings are against non-Muslims and modern scientific thinking and ways of life. As has been made clear in this article, translators are more likely to err in their rendition of the Qur'anic text when they follow an atomistic and/or literalist approach, paying attention to words and verses as if they were in isolation, often either due to following earlier translators uncritically or not paying attention to the important feature of wujūh. ${ }^{36}$ It is essential for all involved in the interpretation and translation of the Qur'an to keep the siyāq, whether siyāq al-nașs or siyāq al-mawqif, firmly in mind.

\section{NOTES}

1 al-Qazwīnī, Sharh al-Talkhīṣ, p. 14.

2 Hassan, al-Lughat al-'Arabiyya, pp. 337 and 372.

3 Ibn al-Athīr, al-Mathal al-sā'ir, vol. II, p. 4.

4 Ibn 'Abbās (d.68/687) and 'Alī b. Abī Ṭālib (d. 41/661) commented on this feature of Qur'anic style. As Qur'anic studies developed, separate studies were made of it, carrying various names such as al-Ashbāh wa'l-naz̄ā ir (by Muqātil b. Sulaymān, d. 150/767), al-Tașārīf (by Yạ̣ya b. Salām, d.200/815), Mā ittafaqa lafẓuhu wa-ikhtalaf ma 'nāhā (by al-Mubarrad, d. 285/898), and al-Wujūh wa'l nazā̄ir fi'l Qur'ān (by al-Damighān̄i, d.478/1085). Muqātil's book, which became better known as al-Wujūh wa'l-naża 'ir fí'l-Qur'ān is a good example. In it he discussed 185 of these wujūh. They can be classed under twelve headings, starting with one word that 
carries seventeen wujūh and ending with 42 words each carrying two wujūh. Muqātil's book and subsequent compilation clearly indicate the extent of the spread of this feature in the Qur'an, which, as will become clear, makes it an important issue in translating the Qur'an.

5 See, for example, the relevant entries in Lane's Lexicon and Wehr's Arabic-English Dictionary.

6 See Watt and Bell, Introduction to the Qur'an, p. 169.

7 Abū Ḥayyān, al-Baḥr al-muhīṭ, 2:123

8 Hassan, al-Sab 'al-mathānī.

9 al-Mu 'jam al-wasìt, vol. 2, p. 1,056.

10 al-Rāzī, al-Tafsìr al-kabìr,part 30, vol. 15, p. 194.

11 al-Bayḍāwī, Tafsīr al-Baydawī, vol. 2. p. 427.

12 It is God who sends the winds, bearing good news of His coming grace, and when they have gathered up the heavy clouds, We drive them to a dead land where We cause rain to fall, bringing out all kinds of crops, just as We shall bring out the dead. Will you not reflect?

13 It is God who sends out the winds; they stir up the clouds; He spreads them over the skies as He pleases; He makes them break up and you see the rain falling from them. See how they rejoice when He makes it fall upon whichever of His servants He wishes.

14 It is God who sends forth the winds' they raise up clouds; We drive them to a dead land and with them revive the earth after its death: such will be the Resurrection.

15 See Divine Oaths in the Qur'an, Occasional Paper 1, 2013, p.49.

16 E.g. Rāzī, Tafsīr part 12, pp.100 ff. Al-Bayḍāwī, Tafsīr pp. 283 ff.

17 Cook, The Koran, p. 34. It will be clear from the discussion in this chapter that he is relying on tafsir rather than the text. See also Chapter 3 where Ella Landau-Tasseron is identified as doing the same thing.

18 Cook, The Koran, p. 33.

19 Pope Benedict XVI, 'Faith, Reason and the University', p. 2.

20 Cook, The Koran, p. 33.

21 Șālih, Tafsīr al-nuṣūs, p. 239; Hassān, al-Bayān, vol. 1, p. 181.

22 al-Rāzī, al-Tafsìr al-kabīr, vol. 5, pp. 107-108. See also the commentary of Ahmad b. 'Abd Allāh b. Humayd on Sharh al-Mahallì 'alā'l-waraqāt, section on $a m r$. Available at www.drmahmoud.com. Others have argued that permissibility should be deduced from the context.

23 This is agreed by all jurists. See Șāliḥ, Tafsìr al-nușūṣ, vol. 2, p. 237.

24 al-Rāzī, al-Tafsìr al-kabìr, part 15, p. 225.

25 The Prophet is also reported to have condemned a Muslim who killed an enemy in battle even after the latter gave him the Islamic greeting, thinking that the man was merely trying to save himself.

26 See Abdel Haleem, The Qur'an, Introduction, p. xxiii. This is one of very few areas where the Qur'an goes into specific details and exceptions. Others areas include rights, such as those of inheritance, and prohibitions, such as the details of who one cannot marry, and in whose company a woman does not have to cover herself completely.

27 That is, inside or outside the Sanctuary. See Abdel Haleem, The Quran, p. 21.

28 See Ibn Salāma, al-Nāsikh wa'l-mansūkh, p. 9.

29 Ibn Salāma, al-Nāsikh wa'l-mansūkh, p. 98.

30 Ibn Salāma, al-Nāsikh wa'l-mansūkh, pp. 94-95.

31 This verse is part of a long section in Sura 2 addressed to the Children of Israel, including nearly 80 verses, starting with verse 40 . 
32 Ibn Salāma, al-Nāsikh wa'l-mansūkh, p. 32-33.

33 Ibn Salāma, al-Nāsikh wa'l-mansūkh, p. 152.

34 Ibn Salāma, al-Nāsikh wa'l-mansūkh, p. 191.

35 Ibn Salāma, al-Nāsikh wa'l-mansūkh, p. 209.

36 So that, for example, hakim always means wise and kitāb always means book and al-nās always means mankind or men. 